\title{
Teknologi pengolahan hasil perikanan untuk meningkatkan perekonomian petani ikan di Desa Sungai Geringging, Kecamatan Kampar Kiri, Kabupaten Kampar, Riau
}

\author{
Sukendi*, Dewita, Thamrin, Ridwan Manda Putra, Windarti, \& Eddiwan \\ Fakultas Perikanan dan Kelautan, Universitas Riau \\ *p.sukendims@yahoo.com
}

\begin{abstract}
Abstrak. Tujuan kegiatan pengabdian kepada masyarakat ini adalah memberikan ilmu dan teknologi kepada anggota Kelompok Usaha Sinar Mentari Desa Sungai Geringging, Kecamatan Kampar Kiri Kabupaten Kampar dalam pengolahan hasil perikanan menjadi produk makanan jajanan berupa otak-otak ikan, kaki naga ikan dan proses cara pemeckingan serta proses penyajian produk yang dihasilkan. Metode yang digunakan adalah metode ceramah, diskusi dan praktek langsung tentang pengolahan hasil perikanan. Hasil evaluasi perubahan pengetahuan terhadap 6 orang anggota Kelompok Usaha Sinar Mentari menunjukkan bahwa 5 orang $(83,33 \%)$ telah dapat menyerap materi yang diberikan dengan predikat sangat baik (nilai A), 1 orang $(16,67 \%)$ dapat menyerap materi yang diberikan dengan predikat baik (nilai B), sedangkan yang memperoleh predikat cukup (nilai C) dan predikat kurang (nilai D) tidak ditemukan. Hasil evaluasi keterampilan yang dilakukan menunjukkan bahwa para anggota kelompok Usaha Sinar Mentari telah mencoba melakukan pengolahan hasil perikanan menjadi produk makanan jajanan berupa otak-otak ikan, kaki naga ikan dan proses cara pemackingan serta proses penyajian produk Sedangkan hasil evaluasi dampak yang dilakukan menunjukkan para anggota kelompok Usaha Sinar Mentari yang merupakan ibu rumah tangga dari anggota Kelompok Pembudidaya Karya Mandiri telah memiliki kegiatan sampingan yaitu mengolah hasil budidaya ikan yang dilakukan oleh para suami mereka.
\end{abstract}

Kata kunci: produk perikanan, otak-otak ikan, kaki naga ikan, proses cara pemackingan, proses penyajian produk

\begin{abstract}
The purpose of this community service activity is to provide knowledge and technology to the community from the Sinar Mentari Business Group, Sungai Geringging Village, Kampar Kiri District, Kampar Regency, in terms of processing fishery products into snack food products in the form of fish brains, fish dragon feet, and processing methods. packing and the process of presenting the resulting product better. The method used is the method of lectures, discussions, and direct practice on how to process fishery products. The results of this evaluation found that there had been a change in knowledge of 6 members of the Sinar Mentari Business Group, which showed that 5 people (83.33\%) had been able to absorb the material given with a very good predicate (grade A), 1 person $(16.67 \%$ ) can absorb the material given with a good predicate (B value), while those who get a sufficient predicate ( $\mathrm{C}$ value) and poor predicate (D value) are not found. Based on the results of this evaluation, it is known that the skill level of the members of the Sinar Mentari Business group, it turns out that they have been able to process fishery products into snack food products in the form of fish brains, fish dragon legs and the process of packing as well as the process of presenting products independently and better. Meanwhile, the impact of this activity is that the housewives of Karya Mandiri Cultivator Group members have succeeded in having side activities to help their family's economy in the form of processing fish farming products
\end{abstract}

Keywords: fishery products, fish brains, fish dragon legs, packing method, product presentation process

To cite this article: Sukendi., Dewita., Thamrin., R. M. Putra., Windarti., \& Eddiwan. 2020. Teknologi pengolahan hasil perikanan untuk meningkatkan perekonomian petani ikan di Desa Sungai Geringging, Kecamatan Kampar Kiri, Kabupaten Kampar, Riau. Unri Conference Series: Community Engagement 2: 498-505. https://doi.org/10.31258/unricsce.2.498-505

(C) 2020 Authors

Peer-review under responsibility of the organizing committee of Seminar Nasional Pemberdayaan Masyarakat 2020 


\section{PENDAHULUAN}

Desa Sungai Geringging merupakan salah satu desa yang terletak di Kecamatan Kampar Kiri Kabupaten Kampar Riau yang memiliki prospek pengembangan perikanan air tawar, berupa pembenihan untuk menghasilkan benih, maupun budidaya ikan dalam keramba dan kolam untuk menghasilkan ikan konsumsi. Hal ini karena desa tersebut berbatasan dengan bendungan Sungai Paku sehingga sumber air untuk kegiatan pembenihan dan budidaya ikan sangat mendukung. Kelompok Budidaya Karya Mandiri adalah salah satu kelompok tani yang bergerak dibidang perikanan yang terdapat di Desa Sungai Geringging, Kecamatan Kampar Kiri, Kabupaten Kampar, dengan jumlah anggota tetap 10 orang. Kelompok ini bergerak dalam bidang budidaya ikan, baik di kolam maupun di keramba yang ditempatkan di bendungan Sungai Paku. Jenis ikn yang dibudidayakan terutama ikan baung, ikan nila, ikan patin dan ikan lele.

Jumlah dan kualitas benih yang baik menentukan keberhasilan dalam usaha budidaya, untuk Kelompok Budidaya Karya Mandiri persoalan untuk mendapatkan jumlah dan kualitas benih yang dibutuhkan untuk pembesaran/budidaya sudah dapat diatasi oleh anggota kelompok melalui pemijahan buatan yang dilakukan. Hal ini karena tim pelaksana pengabdian sudah melakukan kegiatan pengabdian melalui kegiatan pengabdian dengan topik "Penerapan teknologi pembenihan ikan baung (Mystus nemurus CV) pada kelompok Pembudidaya Ikan Karya Mandiri, Desa Sungai Geringging Kecamatan Kampar Kiri, Kabupaten Kampar, Riau" (Sukendi, Thamrin, Zulkarnaini dan Putra, 2016). Selanjutnya persoalan teknologi budidaya telah diselesaikan pula melalui kegiatan Ipteks Bagi Masyarakat (IbM) dengan topik "IbM Kelompok Pembudidaya Ikan Alam Bendungan, Desa Sungai Paku dan Kelompok Tani Karya Mandiri, Desa Sungai Geringging Kecamatan Kampar Kiri, Kabupaten Kampar, Riau (Sukendi, Putra dan Nur' Asiah, 2014). Sampai saat ini persoalan yang belum bisa diselesaikan oleh Kelompok Pembudidaya Ikan Karya Mandiri, Desa Sungai Geringing sampai saat ini adalah belum dikuasainya tentang teknologi pengolahan ikan hasil budidaya yang diperoleh, sehingga pada saat panen ikan hanya bisa dijual dalam bentuk segar sehingga harga ikan akan jatuh sekaligus akan menyebabkan kerugian bagi para petani ikan. Dengan mengetahui teknik pengolahan ikan hasil budidaya nantinya maka ikan tidak hanya dijual dalam bentuk segar tetapi bisa juga dijual dalam bentuk hasil olahan sehingga harga ikan tidak akan jatuh, dengan demikian akan dapat meningkatkan pendapatan sekaligus akan meningkatkan kesejahteraan para petani ikan, kususnya Kelompok Pembudidaya Ikan Karya Mandiri, Desa Sungai Geringing, Kecamatan Kampar Kiri Kabupaten Kampar. Kegiatan teknologi pengolahan hasil perikanan yang dilakukan di Desa Sungai Geringging, Kecamatan Kampar Kiri, Kabupaten Kampar, Riau ini merupakan kegiatan pengabdian kepada masyarakat program desa binaan tahun kedua (2020). Kegiatan pengabdian kepada masyarakat program desa binaan tahun pertama (2019) sudah dilakukan dan telah berhasil membentuk kelompok dengan nama "Usaha Sinar Mentari" yang anggotanya berjumlah 10 orang terdiri dari ibu-ibu rumah tangga dari anggota Kelompok Pembudidaya Sinar Mentari. Pada kegiatan tahun pertama ini juga sudah berhasil memberikan ilmu dan teknologi kepada anggota kelompok Usaha Sinar Mentari tentang teknologi pegolahan hasil perikanan menjadi makanan jajanan berupa snack ikan, nugget ikan dan bakso ikan

Tujuan dari kegiatan pengabdian kepada masyarakat program desa binaan tahun kedua (2020) ini untuk memberikan ilmu dan teknologi kepada anggota Kelompok Usaha Sinar Mentari dalam pengolahan hasil perikanan menjadi produk makanan jajanan berupa otak-otak ikan, kaki naga ikan dan proses cara pemeckingan serta proses penyajian produk yang dihasilkan.

\section{METODE PENERAPAN}

Metode yang digunakan untuk mencapai tujuan yang telah ditetapkan adalah metode diskusi, ceramah dan metode praktek (learning by doing). Dengan melakukan metode diskusi, ceramah dan praktek ini diharapkan dapat meningkatkan pemahaman dan keterampilan masyarakat sasaran dalam hal ini ibu-ibu anggota Kelompok Usaha Sinar Mentari, Desa Sungai Geringging Kecamatan kampar Kiri, Kabupaten Kampar, berkaitan dengan teknologi pengolahan hasil budidaya menjadi makanan jajanan berupa otak-otak ikan, kaki naga ikan dan proses cara pemeckingan serta proses penyajian produk yang dihasilkan. Evaluasi keberhasilan kegiatan pengabdian kepada masyarakat ini dilakukan melalui evaluasi perubahan pengetahuan, evaluasi keterampilan dan evaluasi dampak.

\section{Evaluasi perubahan pengetahuan}

Evaluasi perubahan pengetahuan dilakukan dengan pre test dan post-test. Selisih antara post-test dan pre test dinyatakan dalam persen (\%). Pertambahan tersebut merupakan perubahan pengetahuan yang terjadi selama kegiatan penyuluhan dan percontohan dilakukan. 


\section{Evaluasi keterampilan}

Evaluasi keterampilan dilakukan dengan cara menghitung beberapa keberhasilan teknologi pengolahan hasil perikanan menjadi makanan jajanan berupa otak-otak ikan, kaki naga ikan dan proses cara pemeckingan serta proses penyajian produk yang dihasilkan oleh ibu-ibu anggota Kelompok Usaha Sinar Mentari, Desa Sungai Geringging, Kecamatan Kampar Kiri

\section{Evaluasi dampak}

Evaluasi dampak dilakukan dengan cara observasi langsung di lapangan dan melihat dampak kegiatan yang telah dilakukan terhadap perubahan yang terjadi, terutama tentang teknologi pegolahan hasil perikanan menjadi makanan jajanan berupa otak-otak ikan, kaki naga ikan dan proses cara pemeckingan serta proses penyajian produk yang dihasilkan oleh ibu-ibu anggota Kelompok Usaha Sinar Mentari, Desa Sungai Geringging, Kecamatan Kampar Kiri.

\section{HASIL DAN KETERCAPAIAN SASARAN}

Kegiatan pengabdian kepada masyarakat yang dilakukan telah terlaksana dengan baik. Kegiatan pengabdian yang dilakukan fokus pada kegiatan teknologi pengolahan hasil perikanan menjadi makanan jajanan berupa otak-otak ikan, kaki naga ikan dan proses cara pemeckingan serta proses penyajian produk yang dihasilkan oleh ibu-ibu anggota Kelompok Usaha Sinar Mentari, Desa Sungai Geringging, Kecamatan Kampar Kiri.

\section{Peninjauan tindak lanjut kegiatan pengabdian kepada masyarakat program desa binaan yang sudah dilakukan pada tahun pertama (2019)}

Hasil peninjauan yang dilakukan oleh tim pelaksana terhadap Kelompok Usaha Sinar Mentari tentang tindak lanjut kegiatan pengabdian kepada masyarakat program desa binaan yang sudah dilakukan pada tahun pertama menunjukkan bahwa anggota kelompok Usaha Sinar Mentari yang lokasinya berada pada rumah ketua kelompok Pembudidaya Ikan Karya Mandiri aktif melaksanakan kegiatan sesuai dengan ilmu dan teknologi yang telah diberikan sebelumnya. Hal ini terlihat bahwa anggota kelompok Usaha Sinar Mentari melaksanakan pengolahan hasil perikanan menjadi beberapa produk makanan seperti yang telah diajarkan sebelumnya. Bahkan anggota kelompok Sinar Mentari bukan saja memproduksi pengolahan hasil perikanan, tetapi juga memproduksi produk dari tanaman yang mereka miliki diantaranya pemproduksi kiripik pisang untuk yang sudah dipecking untuk dijual. Hasil wawancara dengan ketua kelompok Usaha Sinar Mentari menyatakan bahwa ilmu dan teknologi yang diberikan pada kelompok tersebut pada tahun pertama sebelumnya (2019) sangat dirasakan manfaatnya oleh anggota kelompok. Hal ini terbukti hasil perikanan dari budidaya yang dilakkan oleh Kelompok Pembudidaya Ikan Karya Mandiri selama ini dijual dalam bentuk segar, setelah dilakukan kegiatan penyuluhan oleh tim pelaksana ikan hasil budidaya tersebut dapat diolah menjadi beberapa produk makanan seperti snack ikan, nugget ikan dan bakso ikan (Gambar 1).
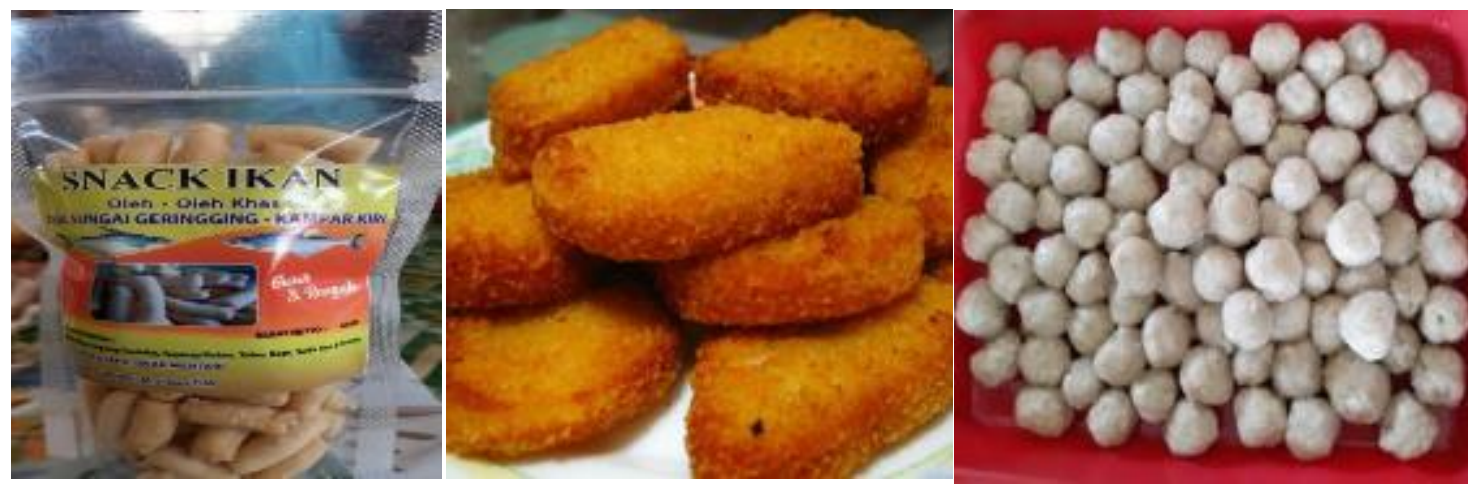

Gambar 1. snack ikan, nugget ikan dan bakso ikan

\section{Penerapan ilmu dan teknologi (Iptek) tentang pengolahan hasil perikanan secara teori dan diskusi}

Penerapan ilmu dan teknologi tentang pengolahan hasil perikanan secara teori dan diskusi tentang teknologi pembuatan otak-otak ikan, kaki naga ikan dan proses cara pemackingan serta proses penyajian produk dilakukan di Balai Pertemuan Desa Sungai Geringging, Kecamatan Kampar Kiri, Kabupaten Kampar, Riau. Kegiatan ini diikuti oleh 6 (enam) orang dari 10 orang anggota Kelompok Usaha Sinar Mentari yang ada. 
Kegiatan ini juga diikuti oleh 9 orang mahasiswa Kukerta yang ada di desa Sungai Geringging, Kecamatan Kampar Kiri, Kabupaten Kampar (Gambar 2). Tim pelaksana pada kegiatan ini memberikan ilmu dan teknologi pengolahan hasil perikanan menjadi produk makanan jajanan berupa otak-otak ikan, kaki naga ikan dan proses cara pemeckingan serta proses penyajian produk yang dihasilkan. Sebelum kegiatan dilakukan tim pelaksana membagikan kuesioner berupa pre test untuk penilaian terhadap evaluasi perubahan pengetahuan sebelum dan sesudah kegiatan dilakukan tentang pengolahan hasil perikanan menjadi produk makanan jajanan berupa otak-otak ikan, kaki naga ikan dan proses cara pemeckingan serta proses penyajian produk yang dihasilkan. Hasil pre test tersebut ternyata rata-rata peserta sebelumnya tidak memiliki pengetahuan sama sekali tentang teknologi pengolahan hasil perikanan menjadi produk makanan jajanan berupa otak-otak ikan, kaki naga ikan dan proses cara pemackingan serta proses penyajian produk yang dihasilkan tersebut.

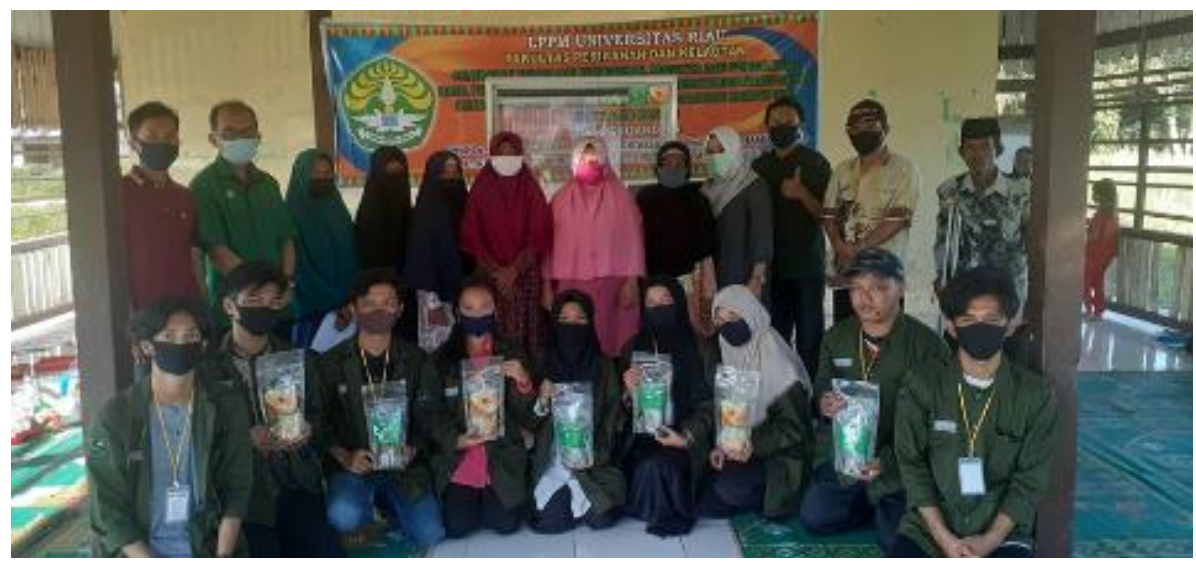

Gambar 2. Dokumentasi keikutsertaan mahasiswa kuekerta UNRI

\section{Penerapan Ilmu dan Teknologi (Iptek) tentang Pengolahan Hasil Perikanan Secara Praktek dan Demonstrasi}

Penerapan ilmu dan teknologi tentang pengolahan hasil perikanan secara praktek dan demonstrasi tentang teknologi pembuatan otak-otak ikan, kaki naga ikan dan proses cara pemackingan serta proses penyajian produk dilakukan di Balai Pertemuan Desa Sungai Geringging, Kecamatan Kampar Kiri, Kabupaten Kampar, Riau. Kegiatan ini juga diikuti oleh 6 (enam) orang dari 10 orang anggota Kelompok Usaha Sinar Mentari yang ada serta 9 orang mahasiswa Kukerta yang ada di desa Sungai Geringging, Kecamatan Kampar Kiri, Kabupaten Kampar. Pada Kegiatan ini dilakukan praktek dan demonstrasi langsung tentang pengolahan hasil perikanan menjadi produk makanan jajanan berupa otak-otak ikan, kaki naga ikan dan proses cara pemackingan serta proses penyajian produk dilakukan. sesuai dengan teori yang telah diberikan sebelumnya. Anggota Kelompok Usaha Sinar Mentari yang ikut dalam kegiatan praktek dan demonstrasi ini sangat antusias mengikutinya terlihat keseriusan dalam mempraktekkan kegiatan yang dilakukan serta banyaknya pertanyaanpertanyaan yang diajukan (Gambar 3). Sebagian besar dari anggota kelompok Usaha Sinar Mentari menyatakan sangat senang sekali kegiatan ini dilakukan, karena sangat membantu mereka dalam penyelesaian masalah yang ditemukan selama ini, yaitu susahnya pemasaran ikan hasil budidaya yang dilakukan oleh para suami mereka pada saat panen, sehingga untuk menghidari agar ikan tidak membusuk terpaksa dijual murah. Perlunya pengolahan hasil perikanan menjadi produk makanan jajanan ini sesuai dengan hasil penelitian yang telah dilakukan sebelumnya, diantaranya produk cake braunes yang difortifikasi dengan KPI (Dewita, Rizky dan Syahrul, 2011), snack Piko Crispe yang difortifikasi dengan KPI ikan (Dewita, Syahrul dan Desmelati, 2014), nugget bonggol pisang yang difortifikasi dengan KPI ikan (Dedy, Dewita dan Suparmi, 2013) dan bubur instan berbahan baku KPI ikan (Dewita dan Syahrul 2011) dan tentang bubur instan dengan penambahan konsentrat protein ikan dengan konsentrasi KPI berbeda (Dewita, Isnaini dan Syahrul, 2012). 


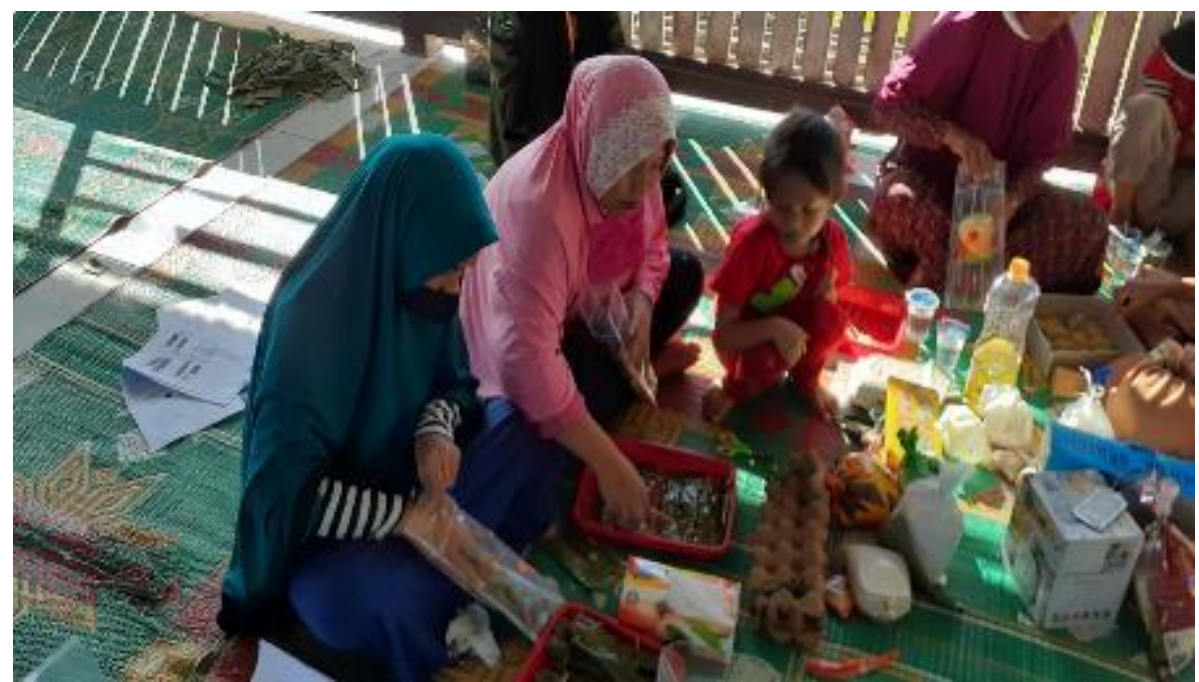

Gambar 3. Anggota Kelompok Mengikuti Kegiatan Dengan Antusias

Menurut pengakuan sebagian besar anggota kelompok Usaha Sinar Mentari juga menyatakan bahwa kegiatan yang dilakukan pada tahun pertama sebelumnya (2019) sangat memberikan manfaat kepada kelompok karena telah berhasil menerapkan ilmu dan teknologi yang diberikan oleh tim pelaksana dalam melakukan pengolahan terhadap hasil budidaya ikan yang dilakukan, hal ini juga sesuai dengan hasil peninjauan oleh tim pelaksana ke lapangan sebelum kegiatan ini dilakukan.

Pada kegiatan penerapan ilmu dan teknologi tentang pengolahan hasil perikanan secara praktek dan demonstrasi tentang teknologi pembuatan otak-otak ikan, kaki naga ikan dan proses cara pemackingan serta proses penyajian produk dilakukan di Balai Pertemuan Desa Sungai Geringging, Kecamatan Kampar Kiri, Kabupaten Kampar ini, tim pelaksana juga menyerahkan sebuah gerobak sebagai asset untuk kelompok Usaha Sinar Mentari yang dapat digunakan sebagai tempat pemajangan hasil produk pengolahan ikan yang dihasilkan sebelum dijual atau dipesan oleh konsumen (Gambar 4). Kegiatan ini juga sudah disosialisasikan melalui media sosial "Koran Riau Pos tanggal 29 Juli 2020" (Gambar 5).

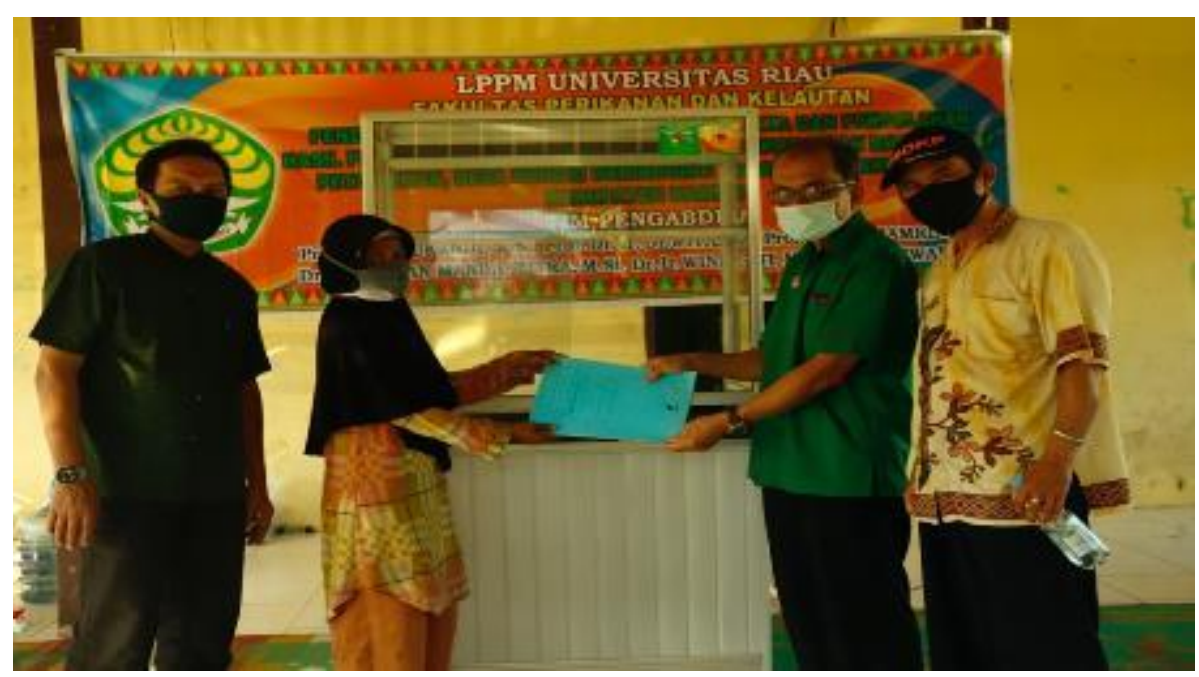

Gambar 4. Penyerahan Gerobak Untuk Jualan Ke Kelompok Usaha Sinar Mentari 


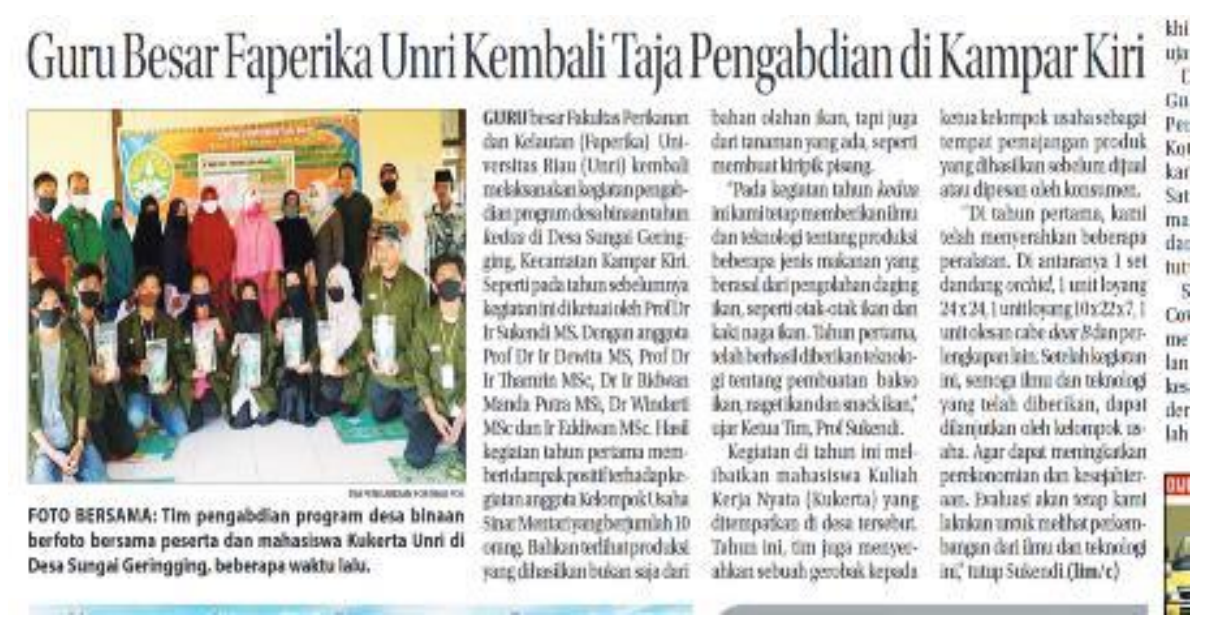

Gambar 5. Publikasi Kegiatan Pengabdian di Media Cetak

\section{Hasil evaluasi perubahan pengetahuan}

Hasil evaluasi perubahan pengetahuan terhadap 6 orang anggota Kelompok Usahan Sinar Mentari Desa Sungai Geringging, Kecamatan Kampar Kiri, Kabupaten Kampar, Riau yang telah dilakukan dapat dilihat pada Tabel 1 dan Gambar 6.

Tabel 1. Hasil evaluasi perubahan pengetahuan kegiatan pengabdian kepada masyarakat program desa binaan tahun kedua (2020) Kelompok Usaha Sinar Mentari, Desa Sungai Geringging, Kecamatan Kampar Kiri, Kabupaten Kampar, Riau.

\begin{tabular}{cccc}
\hline Peserta & Tingkat Penguasaan & Nilai & Predikat \\
\hline $5(83,33 \%)$ & $81-100$ & A & Sangat baik \\
$1(16,67 \%)$ & $71-80$ & B & Baik \\
$0(0,00 \%)$ & $61-70$ & C & Cukup \\
$0(0,00 \%)$ & $51-60$ & D & Kurang \\
\hline
\end{tabular}

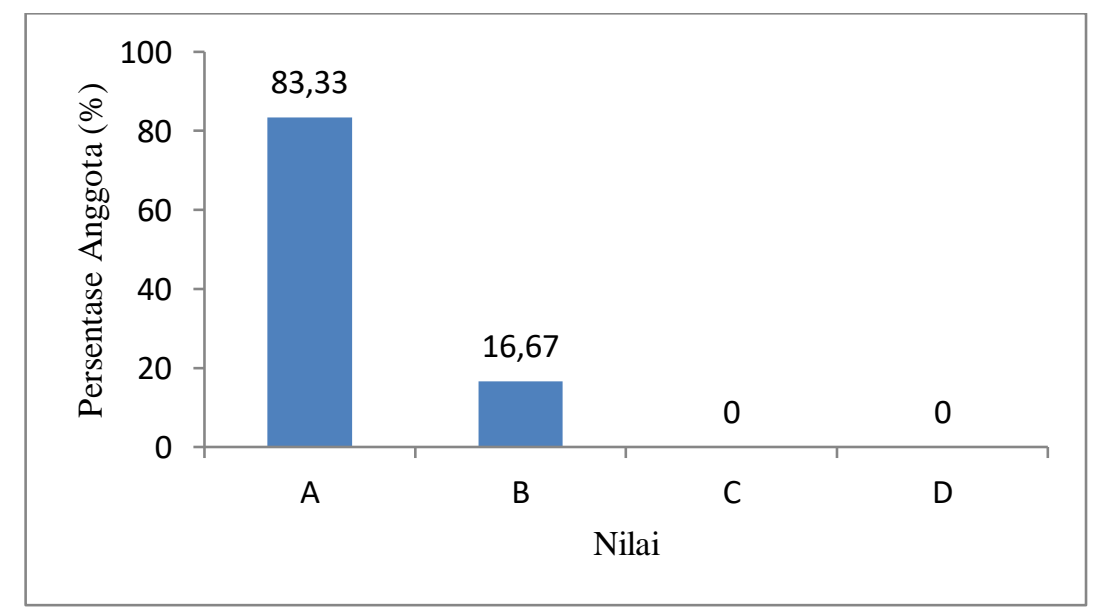

Gambar 6. Histogram hasil evaluasi perubahan pengetahuan kegiatan pengabdian kepada masyarakat program desa binaan tahun kedua (2020 Kelompok Usaha Sinar Mentari, Desa Sungai Geringging, Kecamatan Kampar Kiri, Kabupaten Kampar, Riau.

Dari hasil evaluasi perubahan pengetahuan terhadap 6 orang anggota Kelompok Usaha Sinar Mentari (Tabel 1 dan Gambar 6) menunjukkan bahwa 5 orang $(83,33 \%)$ telah dapat menyerap materi yang diberikan dengan predikat sangat baik (nilai A), 1 orang $(16,67 \%)$ dapat menyerap materi yang diberikan dengan predikat baik (nilai B), sedangkan yang memperoleh predikat cukup (nilai C) dan predikat kurang (nilai D) tidak ditemukan. Tingginya nilai hasil evaluasi perubahan yang diperoleh ini disebabkan karena para peserta benar-benar serius mengikuti kegiatan yang diberikan, baik kegiatan teori dalam bentuk ceramah dan diskusi 
maupun kegiatan praktek dan demonstrasi. Selain itu juga sebagaimana telah diuraikan sebelumnya peserta kegiatan merasa kegiatan yang diberikan benar-benar sangat dibutuhkan untuk meningkatkan penghasilan dan perekonomian usaha budidaya yang dilakukan oleh para suami mereka sebagai anggota Kelompok Pembudidaya Karya Mandiri, Desa Sungai Geringging, Kecamatan Kampar Kiri, Kabupaten Kampar, Riau.

\section{Hasil evaluasi keterampilan}

Hasil evaluasi keterampilan yang dilakukan menunjukkan bahwa para anggota kelompok telah mencoba melakukan pengolahan hasil perikanan menjadi produk makanan jajanan berupa otak-otak ikan, kaki naga ikan dan proses cara pemackingan serta proses penyajian produk yang dilakukan di rumah ketua kelompok Usaha Sinar Mentari, yaitu di rumah Ketua Kelompok Pembudidaya Karya Mandiri yang merupakan pusat kelompok Usaha Sinar Mentari. Kenyataan ini membuktikan bahwa pelatihan yang diberikan sebelumnya telah dipahami oleh anggota Kelompok Sinar Mentari tersebut.

\section{Hasil evaluasi dampak}

Hasil evaluasi dampak yang dilakukan menunjukkan para anggota kelompok yang merupakan ibu rumah tangga dari anggota Kelompok Pembudidaya Karya Mandiri telah memiliki kegiatan sampingan yaitu mengolah hasil budidaya ikan yang dilakukan oleh para suami mereka. Hal ini sesuai dengan hasil evaluasi keterampilan yang telah dijelaskan sebelumnya bahwa para anggota Kelompok Usaha Sinar Mentari telah mencoba melakukan pengolahan hasil perikanan menjadi produk jajanan makanan berupa otak-otak ikan, kaki naga ikan dan proses cara pemackingan serta proses penyajian produk. Dengan dirasakannya dampak kegiatan yang telah diberikan akan dapat pula meningkatkan perekonomian sekaligus meningkatkan kesejahteraan para anggota Kelompok Pembudidaya Karya Mandiri karena hasil budidaya ikan yang dilakukan dapat diolah oleh para ibu rumah tangga yang merupakan anggota Kelompok Usaha Sinar Mentari.

\section{KESIMPULAN}

\section{Kesimpulan}

Dari hasil kegiatan pengabdian kepada masyarakat program desa binaan tahun kedua (2020) yang dilakukan tentang teknologi pembenihan, budidaya dan pengolahan hasil perikanan untuk meningkatkan perekonomian masyarakat petani ikan di Desa Sungai Geringging, Kecamatan Kampar Kiri, Kabupaten Kampar, dengan fokus pada teknologi pegolahan hasil perikanan menjadi makanan jajanan berupa otak-otak ikan, kaki naga ikan dan proses cara pemeckingan serta proses penyajian produk yang dihasilkan dapat disimpulkan sebagai berikut :

1. Kegiatan pengabdian kepada masyarakat program desa binaan tahun kedua (2020) yang dilakukan ini hanya fokus pada teknologi pegolahan hasil perikanan menjadi makanan jajanan berupa otak-otak ikan, kaki naga ikan dan proses cara pemeckingan serta proses penyajian produk yang dihasilkan, hal ini karena teknologi pengolahan tentang pembuatan snack ikan, nugget ikan dan bakso ikan sudah diberikan pada tahun pertama (2019) pada Kelompok Usaha Sinar Mentari.

2. Hasil evaluasi perubahan pengetahuan terhadap 6 orang anggota Kelompok Usaha Sinar Mentari menunjukkan bahwa 5 orang $(83,33 \%)$ telah dapat menyerap materi yang diberikan dengan predikat sangat baik (nilai A), 1 orang $(16,67 \%)$ dapat menyerap materi yang diberikan dengan predikat baik (nilai B), sedangkan yang memperoleh predikat cukup (nilai C) dan predikat kurang (nilai D) tidak ditemukan.

3. Hasil evaluasi keterampilan yang dilakukan menunjukkan bahwa para anggota kelompok Usaha Sinar Mentari telah mencoba melakukan pengolahan hasil perikanan menjadi produk makanan jajanan berupa otak-otak ikan, kaki naga ikan dan proses cara pemackingan serta proses penyajian produk

4. Hasil evaluasi dampak yang dilakukan menunjukkan para anggota kelompok yang merupakan ibu rumah tangga dari anggota Kelompok Pembudidaya Karya Mandiri telah memiliki kegiatan sampingan yaitu mengolah hasil budidaya ikan yang dilakukan oleh para suami mereka.

\section{Saran}

Dari hasil kegiatan pengabdian kepada masyarakat program desa binaan tahun kedua (2020) yang dilakukan tentang teknologi pembenihan, budidaya dan pengolahan hasil perikanan untuk meningkatkan perekonomian masyarakat petani ikan di Desa Sungai Geringging, Kecamatan Kampar Kiri, Kabupaten Kampar, dengan fokus teknologi pegolahan hasil perikanan menjadi makanan jajanan berupa otak-otak ikan, kaki naga ikan dan proses cara pemeckingan serta proses penyajian produk yang dihasilkan disarankan agar kegiatan ini perlu 
dilanjutkan untuk tahun 2021 sesuai dengan peta jalan pengabdian tentang pemasaran produk hasil pengolahan yang telah dipecking sebelumnya.

\section{UCAPAN TERIMAKASIH}

Terimakasih disampaikan kepada Lembaga Penelitian dan Pengabdian Universitas Riau yang telah mendanai kegiatan Pengabdian ini melalui dana DIPA Universitas Riau.

\section{DAFTAR PUSTAKA}

Dewita dan Syahrul. 2010. Kajian konsentrat protein ikan patin dan masa simpannya dalam kemasan berbeda. Laporan Penelitian Hibah Kompetensi Tahun 2010. Lembaga Penelitian Universitas Riau. (tidak dipublikasikan).

Dewita dan Syahrul. 2011. Kajian Diversifikasi Ikan Patin Dalam Bentuk Konsentrat Protein Ikan dan Aplikasinya Pada Produk Makanan Jajanan Untuk menanggulangi Gizi buruk Pada Anak Balita Di Kabupaten Kampar. Prosiding Seminar Antar bangsa Ke-4

Dewita, Rizky dan Syahrul, 2011. Kajian Pola Penerimaan Anak Sekolah Terhadap Produk Makanan Jajanan Berbahan Baku Konsentrat Protein Ikan Baung (Hemibagrus nemurus) di kabupaten kampar, Riau. Prosiding Seminar Nasional dan Pertemuan Ilmiah Tahunan Ke-3 MPHPI tahun 2011 IPB Bogor.

Dewita, Isnaini dan Syahrul, 2012. Inovasi Teknologi Pengolahan Bubur Instan dengan Penembahan Konsentrat Protein Ikan Patin. Jurnal Penelitian Pertanian BERNAS, 8(2).

Dewita, Syahrul dan Desmelati. 2013. Optimalisasi Formula Aneka Mie Sagu Instan yang Difortikasi Konsentrat Ikan Patin Siam (Pangasius hypophthalmus) Sebagai Makanan Potensial Bergizi Tinggi. Jurnal Penelitian BERNAS, $8(2)$.

Sukendi. 2001. Biologi Reproduksi dan Pengendaliannya dalam Upaya Pembenihan Ikan Baung (Mystus nemurus CV) dari Perairan Sungai Kampar Riau. Disertasi Program Pascasarjana Institut Pertanian Bogor.

Sukendi, R. M. Putra dan Yurisman, 2007. Teknologi Pembenihan dan Budidaya Ikan Kapiek (Puntius schwanefeldi Blkr) Dari Perairan Sungai Kampar Riau. Laporan Penelitian Hibah Bersaing Tahun II. Universitas Riau Pekanbaru 